\title{
Automotive recall risk: Impact of buyer-supplier relationship on supply chain social sustainability
}

By Nassar, S, Kandil, T, Er-Kara, M, and Ghadge, A.

\begin{abstract}
Purpose: The purpose of this paper is to examine the automotive product recall risk in terms of social sustainability performance and evaluate the role of buyer-supplier relationships in improving social sustainability during product recall crises.
\end{abstract}

Design/methodology/approach: A multi-methodology approach is used to empirically analyse the interrelationship between the proposed constructs and enablers of the buyersupplier relationship. Structural equation modelling and interpretive structural modelling are followed to analyse the data gathered thorough a questionnaire survey of 204 executives and interviews with 15 managers from the automotive industry.

Findings: The results of the study provide evidence regarding the impact of the responsible buyer-supplier relationship on customer recall concerns and the social sustainability performance of supply chains. This study also leads to the development of a conceptual model providing a relationship between the three key concepts used in this study.

Research implications: Following social sustainability principles, this study addresses the importance of developing strong, responsible, relational ties with suppliers to reduce vehicle recalls or successfully recover from a product recall crisis.

Originality/value: This study contributes to the literature by providing theoretical and empirical insights for developing socially responsible supply chains and confirming the role of the buyer-supplier governance mechanism during product recalls in the context of the automotive industry.

Keywords: Social sustainability, buyer supplier relationship, product recalls, automotive recalls, interpretive structural modelling, supply chains

\section{Introduction}

The economic and environmental dimensions of sustainability are extensively studied (Ahi and Searcy, 2013); However, the social dimension remains fairly under-explored within supply chain management (SCM) literature (Tate and Bals, 2016; Lim et al., 2017). Social 
sustainability incorporates the responsibility of considering stakeholders' rights (Miemczyk and Luzzini, 2016) and incorporates the notion of avoiding irresponsible actions that may harm stakeholders (Grimm et al., 2014). Corporate social responsibility (CSR) and business ethics are two important research streams within sustainable supply chain management (SSCM) (Leppelt et al., 2013; Noack et al., 2017). Social responsibility in supply chains represents implicit and explicit commitment towards stakeholders through incorporating social (and environmental) standards in managing activities (e.g., fair treatment, proper payment, ethical product sourcing) and endeavouring enhancement of ethical and social performance (Matten and Moon, 2008).

Sustainability is an inevitable part of the global automotive industry (SMMT, 2018) due to the high pressure imposed on automotive supply chains to enhance their sustainability practices (Diabat et al., 2013, Schöggl et al., 2016). There is constant pressure from end customers regarding sustainability concerns and from regulatory bodies to comply with incremental, stringent requirements of laws and regulations such as the recent European transformation towards a circular business model (c.f. SMMT, 2018, European Commission, 2015, EU, 2000, 2008). Despite the social sustainability dimension being essential, the automotive industry has shown irregular social behaviour over time (Azevedo and Barros, 2017). Particularly, automotive recall continues to be a major concern and better mechanisms are required to anticipate and mitigate this risk (Aragon et al., 2019). Customer safety is an integral component of the social sustainability performance of automotive supply chains (SCs) and should take top priority for internal and external SC stakeholders (Leppelt et al., 2013; Ciravegna et al., 2013; Kumar and Rahman, 2016).

Product recall is a form of SC risk that occurs as a result of severe quality failure (Zsidisin, 2003; Marucheck et al., 2011). Product recalls are typically associated with outsourcing and off-shoring (Steven et al., 2014), and result in significant adverse consequences such as damage to reputation, long-term financial loss and bankruptcy (Zsidisin, 2003; Shah et al., 2016). Interest concerning product recalls is growing due to accelerating competition and dynamism in markets (Steven et al., 2014; Shah et al., 2016). In 2015, Volkswagen's 'dieselgate scandal' rigged its diesel engines to make its diesel vehicles appear to emit lower toxic pollution in emission tests (Mansouri, 2016). After this unethical action, Volkswagen recalled millions of diesel cars affected worldwide and paid considerable penalties 
to governments and regulatory bodies. In 2017, BMW recalled 312,000 vehicles in the UK and Ireland due to a potentially fatal electrical failure (Fritz, 2018). The growing number of product recalls of global brands, primarily in the automotive industry, is a vivid signal of failures in SCs that are mostly related to manufacturing-related problems, outsourcing issues and global operations (Marucheck et al., 2011; Steven et al., 2014; Shah et al., 2016; Lim et al., 2017).

Product recalls should be examined together with other external factors that affect social sustainability of SCs, e.g., stakeholder partnership, committed long-term relationship, trust between SC partners, knowledge management and information sharing (Grimm et al., 2014; Lim et al., 2017). In recent years, various researchers have highlighted the importance of expanding sustainability across SC networks (Wilhelm et al., 2016a). The public's growing pressure for CSR and expansion of this pressure to supplier and sub-supplier level increases the importance of upstream SCs to improve their ethical and responsible approach towards doing business (Gualandris and Kalchschmidt, 2016). Extant literature shows the scarcity of theoretical frameworks addressing the relationship between social responsibility in SCs and the extent to which manufacturers/buyers and suppliers perform ethically and responsibly during a damaging event such as product recall (Shah et al., 2016; Kordestani et al., 2014). Such events may be seen as a signal for poor buyer-supplier relationships which, in turn, may affect the social sustainability performance of the SC network.

Past research has identified a number of sustainability challenges including increased stakeholder and regulatory pressure combined with a lack of understanding on how SCM decisions affect society and the environment in different regions (Wilhelm et al., 2016; Seuring and Müller, 2008). Social aspects of both SC performance and sustainability are relatively understudied due to the complexity of developing associated measures (Tate and Bals, 2016; Azevedo and Barros, 2017). In recent years, assessment of the social lifecycle has become imperative for assessing the corporate social profile and social impact of products throughout their entire lifecycle (Tsalis et al., 2017). However, product recall risks and their impact on social sustainability are largely overlooked (Bruccoleri et al., 2018). Especially, there is an alarming trend, globally, in the frequency, intensity and cost of vehicle recall concerns (Steven et al., 2014; Allianz, 2017). Myriad factors and dynamics trigger product recall, and lack of knowledge exists in understanding and managing this risk. Recall concerns and their impact on social sustainability should be evaluated at the SC- rather than firm-level. 
Another gap exists concerning how sustainability is seen from different actors' perspectives. Traditional business models mainly focus on manufacturers' concerns and less attention is given to customers' perspectives, especially for social sustainability issues (Wells, 2008; Schöggl et al., 2016). In order to contribute to the aforementioned research gaps, this study examines the product recall risk and relevant customer concerns in terms of social sustainability performance and further analyses the role of the buyer-supplier relationship in improving social responsibility during a product recall crisis.

This paper investigates the risk of automotive recall in terms of its impact on the social sustainability performance of the SC and assesses the role of the buyer-supplier relationship in potentially improving social sustainability performance during such a crisis. A multi-faceted perspective is followed to examine product recall risk in SCs in relation to CSR, social sustainability and supplier-buyer relationships. The study provides a comprehensive analysis through the integration of interpretive structural modelling (ISM) and structural equation modelling to enhance the empirical findings of the study. First, the key enablers of the buyersupplier relationship and indicators of sustainability performance are identified through a critical review of the literature and discussion with industry experts. Later, an ISM methodology is applied to analyse the interrelationships between the enablers of the buyersupplier relationship. The relationship between latent variables such as the social sustainability performance of SCs, buyer-supplier relationship and automotive recall concerns are examined by employing a covariance-based structural equation modelling (CBSEM) approach. The data set for the analysis was gathered thorough a survey of 204 executives and interviews with 15 managers from the automotive industry.

This study contributes to the literature of buyer-supplier relationships and SC social sustainability performance by introducing the context of UK automotive recalls and customers' concerns in downstream relationships (in the B2B market), a subject that has been neglected in the literature (Leppelt et al., 2013). Moreover, the present work provides theoretical and empirical insights concerning the role and importance of buyer-supplier relationships in the recovery from product recall crises and improvement in social sustainability.

The rest of the paper is structured as follows: Section 2 presents interlinking literature on social sustainability performance, product recall, and the buyer-supplier relationship to provide a baseline for the proposed approach. Section 3 describes the research methodology. Section 4 introduces the proposed structural model, explains the methodological steps and discusses the 
results of the ISM and CBSEM methodologies. Finally, the study concludes with theoretical and practical implications, limitations and possible future research directions.

\section{Literature review}

\subsection{Social sustainability performance and product recalls in the automotive industry}

In recent years, social responsibility and sustainability has been receiving increased attention in the sustainability literature (Kumar and Rahman, 2016, Wilhelm et al., 2016). Garbie (2014) lists the essentials of social sustainability as work management issues, human rights, societal commitment, customers' issues, and business practices. The social sustainability performance of SCs considers the social impacts throughout a product's lifecycle to ensure that environmental and social responsibilities are addressed (Hutchins et al., 2008; Benoît et al., 2010). For the automotive industry, social sustainability performance of SCs has five dimensions - social and environmental responsibility, flexibility, responsiveness, automotive quality, and sustainable knowledge management (Agustin and Schröder, 2015; Bhattacharya, et al., 2014; Thomé et al., 2014; Stadtler, 2015). Social sustainability performance of automotive SCs is a major concern due to increasing pressure for additional sustainable practices from end-customers (Leppelt et al., 2013; Flynn et al., 2015; Gualandris and Kalchschmidt, 2016). The main sustainability challenges facing the automotive industry include high variation in styles and models along with developments in technical and smart features (Wells, 2013). This entails massive variation and complexity in SCM processes including $\mathrm{R} \& \mathrm{D}$, supply, manufacturing, distribution, logistics and relationship management (Quesada et al., 2006). Such complexity is augmented during a product-harm crisis, including product recalls that have damaging consequences on business (Chen et al., 2009). Social sustainability of SCs is important in order to achieve positive social/ethical performance during product recall (Kumar and Rahman, 2016).

The UK Driver and Vehicle Standards Agency (DVSA, 2014) defines a vehicle related safety defect as: "a failure due to design and/or construction, which is likely to affect the safe operation of the product/aftermarket part without prior warning to the user and may pose a significant risk to the driver, occupants and others". Automotive recalls might result in huge financial as well as non-financial losses and it may take longer to recover from the undesired consequences (Rupp, 2004; Zhao et al., 2013). The cost of recalls includes communication and 
advertising costs, lost sales, inventory losses, cost of refund/compensation, logistics costs and fines/lawsuits. These events diminish profits, decrease customer trust and cause severe harm to the reputation of the company (Bates et al., 2007; Kumar and Schmitz, 2011). From an end customer and market perspective, a lower recall rate is regarded as a positive signal indicating that the manufacturer is effectively managing not only the production process but, also, the entire SC network.

In recent years, the total number of reported product recalls and the volume of recalled products have increased exponentially (Shah et al., 2016). The automotive sector accounts for over $70 \%$ of the value of total losses resulting from product recall events and their triggering effects (Allianz, 2017). Statistics show a globally increasing trend in the frequency, intensity and severity of vehicle recall events. In Europe, automotive recalls have increased by $73.6 \%$ in the first quarter of 2019 (Stericycle, 2019). Trends towards product differentiation, modular design, SC partnership and common product platforms increase product recall risks due to the complexity of the network, diversification of products, dependency on suppliers and other stakeholders and, the possibility, of cross-defect impact (Aragon et al., 2019). In the UK, the DVSA checks and monitors outstanding vehicle recalls with tests conducted by the Ministry of Transport (MOT). Currently, nearly 2.39 million cars in the UK are estimated to have outstanding safety recall, resulting in one in 13 cars likely to fail its MOT test (Hull, 2019). These statistics provide evidence of serious vehicle recall challenges, thus demanding the need for collaborative management approaches to mitigate the vehicle recall risk in automotive SC networks.

Ensuring product quality and safety is the responsibility of all stakeholders across an SC network (Ni et al., 2014). The increase in product recalls of global brands, especially in the automotive industry, highlights the issue of failures in SC operations ( Marucheck et al., 2011; Steven et al., 2014; Lim et al., 2017). Automotive recall concerns in the downstream SC might be seen as a signal for poor buyer-supplier ethical ties in the upstream SC that, in turn, might affect social sustainability performance throughout the chain. Outsourcing has become an effective practice in the automotive industry, and its adoption scope and scale show an incremental trend in the incorporation of partial and full-service vehicle supplies (Ciravegna et al., 2013). Automakers obtain their resources from hundreds of suppliers across the globe, and offshore sourcing has a significant influence on recalls (Steven et al., 2014). Thus, a responsible 
and ethical buyer-supplier relationship is crucial to mitigate such complications (Narayanan and Narasimhan, 2014).

\subsection{Responsible buyer-supplier relationship for sustainability performance}

The major challenge in managing a contemporary SC (such as automotive SC) is the intensified interdependency among its activities and stakeholders that, in turn, requires appropriate governance mechanisms for its effective management (Turnbull et al., 1992; Corsten et al., 2011; Ciravegna et al., 2013). Governance between business stakeholders/partners is defined as the relationship mechanism that directs parties' behaviour with the aim of achieving some shared goals (Griffith and Zhao, 2015). Opportunistic behaviour, goal differences and different operational routines are key drivers of transformation towards non-relational governance mechanisms (Dyer and Singh, 1998; Zheng et al., 2008). Liu et al. (2012) found that transactional and relational mechanisms are both effective in enhancing operational performance. It is argued that socially responsible activities have a direct and positive impact on SC performance through the mediation effect of cooperation and trust (Carter and Jennings, 2002).

It is contended that trust, openness and honesty are among the most important factors in developing a successful long-term responsible and ethical relationship (Spence and Bourlakis, 2009; Gualandris and Kalchschmidt, 2016). Additionally, communication, information sharing, commitment, knowledge management and partnership development are significant for socially responsible SCs (Van Tulder et al., 2008). In the automotive industry, it is claimed that careful selection of suppliers, constant development of suppliers and close monitoring of their performance have a positive impact on social dimensions of sustainability (Kumar and Rahman, 2016). Furthermore, it is contended that power can predict sharing of value and sustainability-related risks among SC partners (Touboulic et al., 2014).

\section{Research methodology}

The study follows a multi-methodological approach to examine the links between social sustainability performance, product recall risk and the buyer-supplier relationship. An ethical and contractual relationship framework, adapted from Leppelt et al. (2013), is used to showcase responsible upstream and downstream relationships in automotive SCs. A socially responsible SCM structure is represented by incorporating upstream and downstream 
stakeholders as shown in Figure 1. The dotted arrows refer to socially responsible or ethical SC relationships, and the solid arrows represent the contractual relationships. Social SCM is described as the integrated feedback of key SC processes from the end customer (Grimm et al., 2014; Kumar and Rahman, 2016). The setting of social SC performance is presented in a cross-functional framework. This would be implemented while addressing the following two issues: i) Examine SCM from a social sustainability performance perspective, and ii) explain how ethical collaborations of upstream and downstream partners of the buyers affect social sustainability performance and related SC decisions. Based on the literature review, five main dimensions are identified for the sustainability performance of SCs in the automotive industry. The identified dimensions are validated using the data collected from the UK automotive sector.

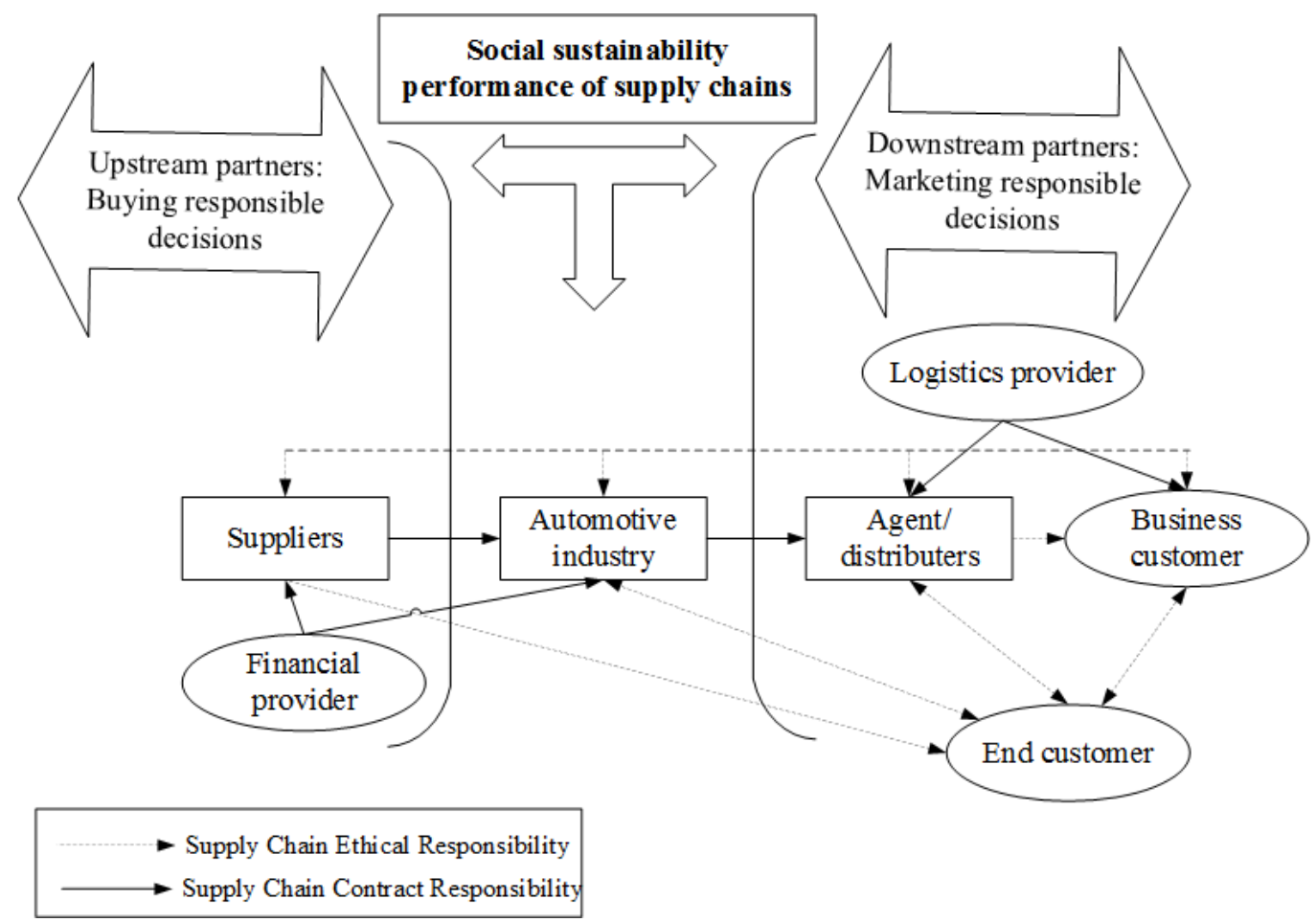

Figure 1. Responsible upstream and downstream relationships in automotive SCs

First, an interpretive structural modelling (ISM) method is used to analyse the identified enablers of the responsible buyer-supplier relationship; in the second stage, a theoretical model is developed to show the interrelationships among these enablers. ISM is widely accepted to determine the structure of any social or technical system (Attri et al., 2013). This study uses an 
ISM approach to establish how responsible buyer-supplier relational ties influence the social sustainability performance of SCs during periods of automotive recall. The study combines both a triangulation method for data collection (ISM) and a linear structural relationship of SEM to build the models, along with the help of experts from the automotive industry.

The proposed structural relationship modelling between latent variables can be understood by using several manifest variables (Caniëls et al., 2013; Wilhelm et al., 2016a). In order to achieve the aim of the present study, a CBSEM approach has been used to interpret the impact of responsible buyer-supplier relationships on managing product recall concerns. The proposed methodology examines the interrelationships between three main research variables considering the magnitude of the individual as well as the total impact.

Safety recall happens when an automotive manufacturer identifies safety concerns related with design or production defects in their cars. If a vehicle recall occurs, the automotive manufacturer tries to trace all affected vehicles to rectify the defects (Caniëls et al., 2013; Kumar and Rahman, 2016; Miemczyk and Luzzini, 2016). The safety recall is a strategic concern in the UK automotive market. Nearly half of the vehicles registered in the UK (10.8 Million vehicles) were recalled between 1992-2002, and there was a substantial increase between 1998 and 2002 (Bates et al., 2007). In the US, since the 1990s, annual vehicle recalls have almost doubled, and in 2002 over 19 million vehicles were recalled (Consumers Union, 2004). Recall rates can be used as an indicator of process performance in the automotive value chain (Amann et al., 2014; Wilhelm et al., 2016a). The present study addresses the impact of automotive industry recalls on the social sustainability performance of SCs based on the data collected from automotive companies in the UK. A questionnaire survey was sent to 450 executives in the automotive sector. A total of 204 people participated, yielding a response rate of $45.33 \%$. The preliminary scales used in the questionnaire survey were tested by interviewing 15 SC managers from the automotive industry, who closely deal with buyer-supplier relationships. Details of the dimensions of the social sustainability performance of SCs were explained to the managers during the interviews. Each interview took about one to one-and-ahalf hours. Finally, 30 scale items were identified based on the results of this pilot test. Each item was assessed by a five-point Likert scale to measure four latent variables of the buyersupplier relationship, three latent variables of vehicle recall concerns and three latent variables of social sustainability performance (Scale-1: Strongly disagree, 5: Strongly agree). 


\section{Analysis and development of a conceptual model}

\subsection{Identification of social sustainability performance indicators for automotive SCs}

Following previous classifications of sustainability indicators provided by Agustin and Schröder (2015), Bhattacharya, et al. (2014), Thomé et al. (2014) and Stadtler (2015), sustainability indicators of automotive SCs are examined under five main categories. These categories are explained below.

i) Social and environmental responsibility:

Nowadays, socially and environmentally responsible logistics is a rapidly emerging concern among academia and industry. Therefore, automotive manufacturers give increasing attention to the social and environmental issues in their SC operations. Especially, pollution prevention and vehicle recall minimisation are distinctive elements of the automotive operation management strategy (Yeung and Coe, 2015). Efficient use of environmental technologies can help to mitigate product defects and recalls and can be adapted very quickly due to the processbased operations architecture of the automotive industry (Mao and Jin, 2014).

ii) Flexibility:

Flexibility indicators measure the automotive industry partners' capability to adapt their products to the changes (often rapid) in automotive demand or supply (Kumar and Rahman, 2016; Miemczyk and Luzzini, 2016). The dynamism and mobility provided by flexibility can help to increase sales substantially. Process flexibility provides the ability to control output levels easily; therefore, it supports the sustainability performance of SCs during automotive recall cases. Also, flexibility in SCs enables automotive SC partners to maintain sustainability practices resulting in decreased product recalls.

\section{iii) Responsiveness:}

Responsiveness indicators have been considered as a dominant issue in the social sustainability performance of SCs (Mao and Jin, 2014; Meckenstock et al., 2016). Responsiveness indicators replicate the automotive producers to meet customer concerns before and after recall announcements. Measures of responsiveness play a key role in meeting arranged leading times, delivering the quality required by customers, and maximising safety and security levels in the automotive industry. These indicators help to achieve a competitive advantage in many industries by meeting the requirements of sustainable performance.

iv) Automotive quality:

Product quality is a widely used criterion to measure corporate social performance for different 
industries due to its influence on customer satisfaction, health and safety. Quality is particularly crucial in the automotive industry. The quality of customer services is very important for the 'shared social responsibility value' for downstream partners (Wang et al., 2012; Akdeniz et al., 2014).

\section{v) Knowledge management:}

Knowledge management capability in the relationship between buyer and supplier is essential for creating a competitive advantage for business (Lim et al., 2017). Knowledge management delivers value from sustainable SC relationships and provides a platform for SC partners to share corporate responsibility and sustainability. Knowledge management transforms useful information into actions to achieve socially responsible and sustainable SCs.

The structural matrix in Table 1 presents these five dimensions of sustainability performance and relevant criteria.

Table 1. Structural matrix for sustainability indicators in automotive SCs

\begin{tabular}{|c|c|c|}
\hline $\begin{array}{l}\text { Aspects of } \\
\text { Sustainability } \\
\text { Performance }\end{array}$ & Criteria & Reference(s) \\
\hline $\begin{array}{l}\text { Social \& } \\
\text { environmental } \\
\text { responsibility }\end{array}$ & $\begin{array}{l}\text { - Social responsibility } \\
\text { - Work conditions } \\
\text { - Communication \& collaboration } \\
\text { - Product lifecycle } \\
\text { - Lean production }\end{array}$ & $\begin{array}{l}\text { Yeung and Coe, 2015; Lee } \\
\text { and Lam, 2012; Mao and } \\
\text { Jin, 2014; Meckenstock et } \\
\text { al., } 2016\end{array}$ \\
\hline Flexibility & $\begin{array}{l}\text { - Dynamism and mobility of } \\
\text { delivery } \\
\text { - Supply chain partners }\end{array}$ & $\begin{array}{l}\text { Harms, 2011; Mori and } \\
\text { Christodoulou, 2012; Ma et } \\
\text { al., } 2013\end{array}$ \\
\hline Responsiveness & $\begin{array}{l}\text { - Number of product recall } \\
\text { announcements } \\
\text { - Customer concerns } \\
\text { - Competitive advantages }\end{array}$ & $\begin{array}{l}\text { Mao and Jin, 2014; } \\
\text { Meckenstock et al., } 2016\end{array}$ \\
\hline $\begin{array}{l}\text { Automotive } \\
\text { quality }\end{array}$ & $\begin{array}{l}\text { - Design and raw materials } \\
\text { - Quality of logistics } \\
\text { - Customer services } \\
\text { - Distribution quality }\end{array}$ & $\begin{array}{l}\text { Wang et al., 2012; Akdeniz } \\
\text { et al., } 2014\end{array}$ \\
\hline $\begin{array}{l}\text { Sustainable } \\
\text { knowledge } \\
\text { management }\end{array}$ & $\begin{array}{l}\text { - Information/knowledge sharing } \\
\text { - Joint knowledge creation } \\
\text { - Information technology } \\
\text { - Knowledge storage }\end{array}$ & Lim et al., 2017 \\
\hline
\end{tabular}




\subsection{Development of the hypothesis}

SSCM practices are essential for responsible upstream suppliers to ensure the social responsibility performance (SRP) of their downstream buyers. Some researchers in the SSCM literature have noted that close integration of buyers and suppliers might increase the networkbased competitiveness of automotive SCs (Sancha et al., 2016). A close collaboration between both actors positively affects the social sustainability performance of SCs (Fernández et al., 2010). Therefore, the first hypothesis of the present study is identified as follows:

H1: Social responsibility in the buyer-supplier relationship has a positive effect on the social sustainability performance of SCs during an automotive recall crisis.

The ethical and social responsibility in the buyer-supplier relationship is interrelated with the customers' concerns on product recall and the sustainability performance of buyers. Therefore, the second and third hypotheses are identified as follows:

H2: Social sustainability and responsibility in the buyer-supplier relationship during an automotive recall can help to effectively manage customers' concerns resulting from the crisis.

H3: Social sustainability indicators related to customers' automotive recall concerns can help to effectively manage the social sustainability performance of the SC.

The conceptual framework shown in Figure 2 is developed based on these hypotheses. An SEM approach is proposed to analyse these relationships.

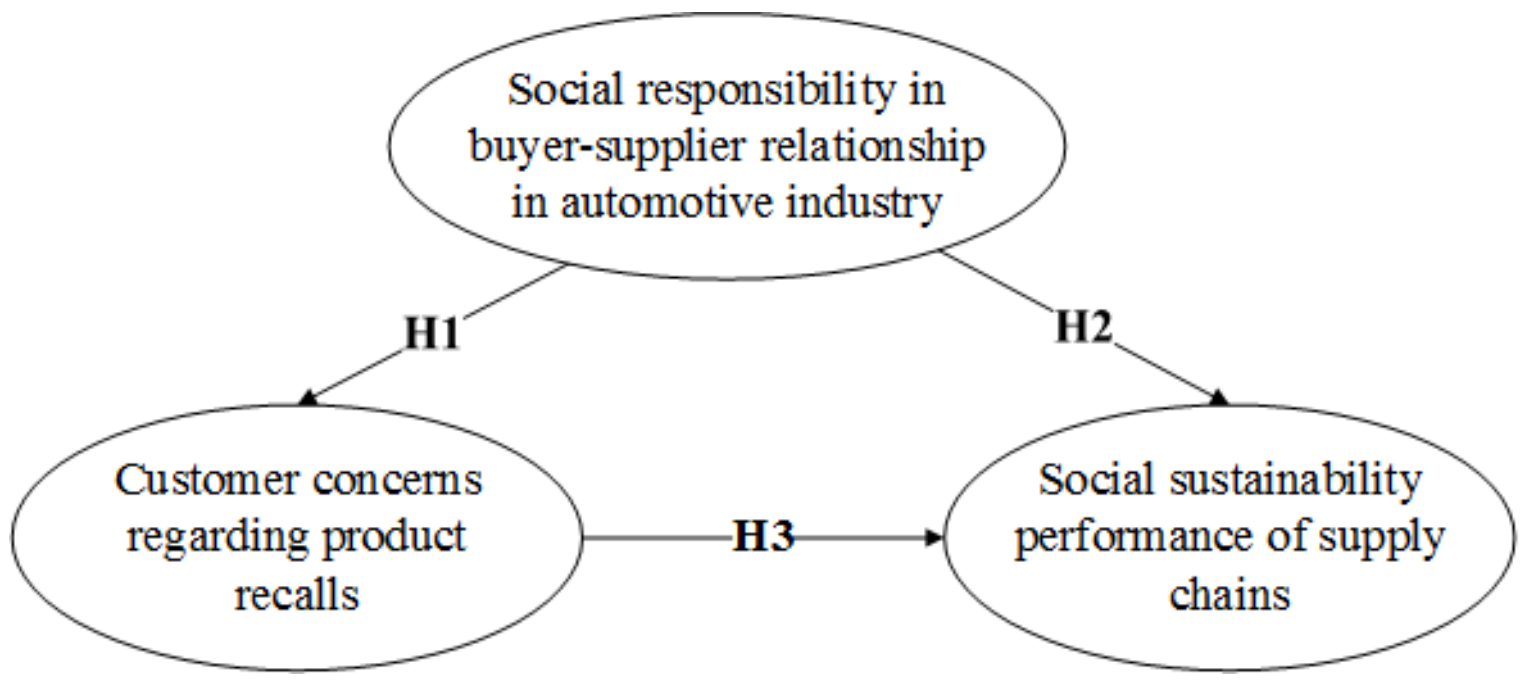

Figure 2. Conceptual model of the study 


\subsection{ISM Methodology}

ISM has been embedded in the present study to provide qualitative factors to measure the impact of the responsible buyer-supplier relationship on customer concerns related to automotive recalls. The ISM methodology can explain the complex pattern of conceptual research variables and their inter-relationships. This study uses the ISM application approach used by Ravi and Shankar (2005) and Kannan et al. (2009):

Step 1: List the variables for social sustainability performance of SCs that affect the variables related to the customer concerns of product recall and responsible buyer-supplier relationship.

Step 2: Establish the pair-wise relationship between the two variables of the research: buyersupplier relationship and automotive recall concerns.

Step 3: Form the structural self-interaction matrix (SSIM) using the assessment criteria that are gathered by discussions with experts.

Step 4: Draw a directed graph (digraph) based on the aforementioned relationships in the matrix.

Step 5: Replace the variable nodes with statements to generate the ISM-based model.

Step 6: Review the ISM model to ensure that conceptual consistency is supplied, and the necessary modifications are made.

The structural model is generated based on the reachability matrix. If there is a relationship between sustainability aspects and variables, then an arrow is drawn to connect the two points or two stages in the hierarchical model. The digraph of the ISM hierarchical model is provided in Appendix 1. There is a direct relationship between the sustainability aspects, and buyer-supplier relationship and social responsibility. Figure 3 covers the sustainability performance improvement aspects. These aspects enhance the sustainability performance of $\mathrm{SC}$ members in relation to customer concerns of automotive recalls. It is very important for the responsible buyer-supplier relationship to ensure social responsibility, work conditions, communication and collaboration, product lifecycle and lean production (social and environmental aspects) which establish a basic foundation to achieve. Furthermore, information/knowledge sharing, joint knowledge creation, information technology, knowledge storage, and social knowledge management play significant roles in improving collaboration and communication during product recall announcements. 


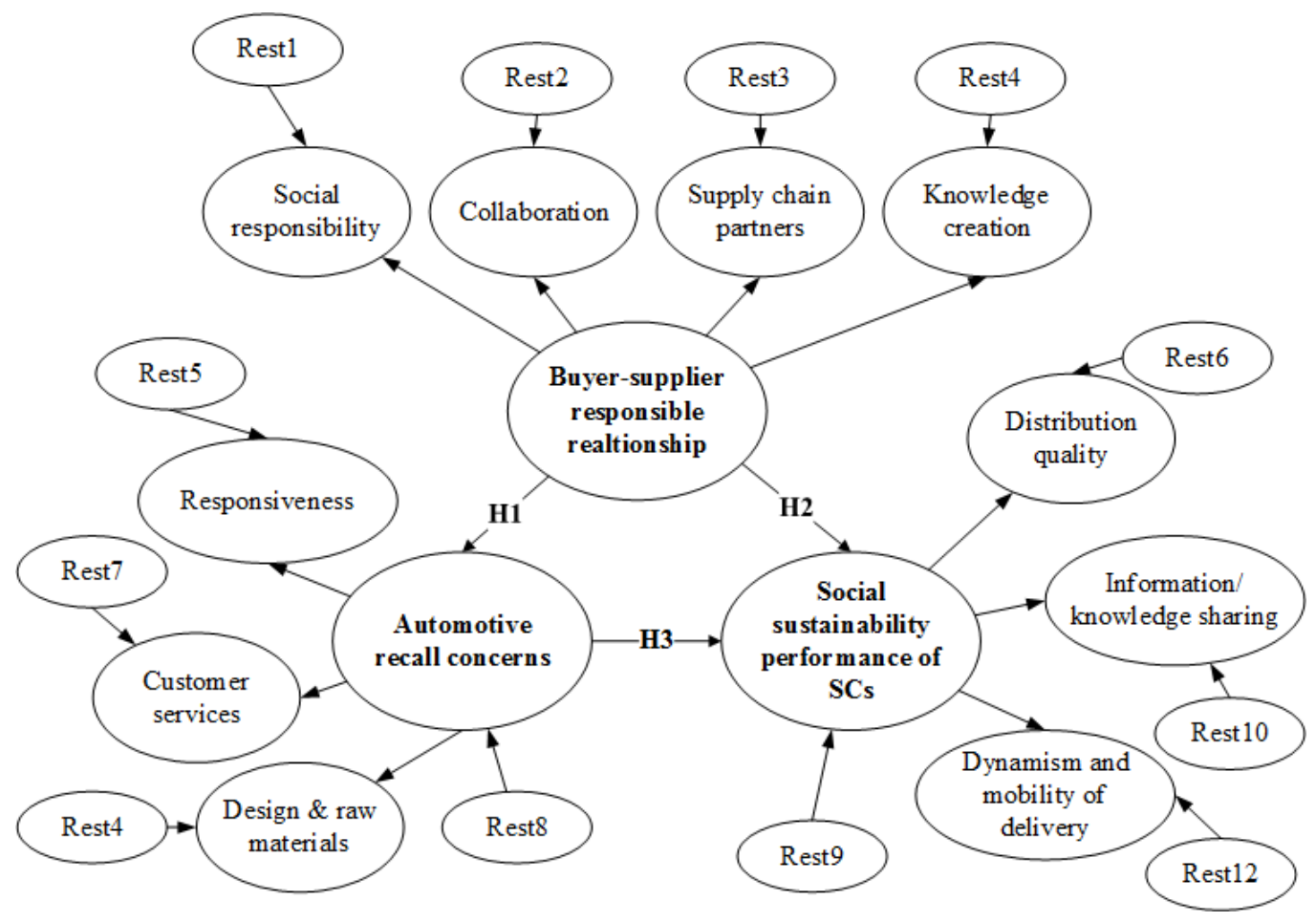

Figure 3. Structure of the hypothesised research model

The final step is aggregating the relationship aspects of sustainability performance with flexibility, automotive quality, responsiveness, sustainable knowledge management and social and environmental responsibility by using upward arrows in the hierarchical model in Appendix 1.

CBSEM methodology involves the estimation of multiple and interrelated dependencies in a single analysis model (Kumar and Rahman, 2016). CBSEM methodology can also test casual relationships. The conceptual model of this study consists of sustainable responsible relationship indicators which are subdivided into criteria and sub-indicators as shown in the structure of the hypothesised research model provided in Figure 3. The main indicators are represented by shaded circles in the middle of the model: buyer-supplier relationship, automotive recall concerns of customers, and social sustainability performance. This model tests the causal relationship between the main research variables of the study.

\subsection{Results of the Covariance Based SEM and Hypothesis Testing}

First, the reliability of data is checked using Cronbach's alpha as shown in Table 2. A Cronbach alpha value that is greater than 0.7 exhibits excellent reliability (Hair et al., 2009). Since all the 
Cronbach's alpha values are greater than 0.7 , this dataset can be regarded as reliable.

Table 2. Sustainable social SC relationship and scale items: standardised CFA path loadings and statistics

\begin{tabular}{lccc}
\hline $\begin{array}{l}\text { Social sustainability } \\
\text { performance and scale items }\end{array}$ & $\begin{array}{c}\text { Standardised } \\
\text { path loading }\end{array}$ & $\begin{array}{c}\text { Critical } \\
\text { ratio }\end{array}$ & $\begin{array}{c}\text { Cronbach's } \\
\text { alpha }\end{array}$ \\
\hline $\begin{array}{l}\text { Social and environmental } \\
\text { responsibility }\end{array}$ & 0.836 & 9.25 & 0.864 \\
$\begin{array}{l}\text { Flexibility } \\
\text { Responsiveness }\end{array}$ & 0.892 & 10.272 & 0.879 \\
$\begin{array}{l}\text { Automotive quality } \\
\text { Sustainable knowledge } \\
\text { management }\end{array}$ & 0.847 & 11.855 & 0.878 \\
& 0.745 & 9.321 & 0.899 \\
\hline
\end{tabular}

${ }^{*}$ Cronbach's alpha values exceed 0.70 exhibit reliability. The critical ratio (CR) and associated p-value for a one-tailed test of significance are as follows: CR1/41.28, p-value o0.10; CR1/41.64, p-value o0.05; CR1/42.33, p-valueo0.01; CR1/43.10, p-valueo0.001.

Then, confirmatory factor analysis (CFA) is applied to test the unidimensionality of the research scales, and the results are presented in Table 3. The chi-square values and associated probability levels are also given in the table. Five measurement models are developed to analyse the dimensions of social sustainability performance.

Table 3. Unidimensionality and reliability analyses of SRSD and CSR scales

\begin{tabular}{|c|c|c|c|c|c|c|c|}
\hline $\begin{array}{c}\text { Social } \\
\text { sustainability } \\
\text { performance and } \\
\text { scale items } \\
\end{array}$ & AGFI & GFI & CFI & NFI & NNFI & $\begin{array}{l}\text { Construct } \\
\text { reliability }\end{array}$ & $\begin{array}{l}\text { Average } \\
\text { variance } \\
\text { extracted }\end{array}$ \\
\hline $\begin{array}{l}\text { Social and } \\
\text { environmental } \\
\text { responsibility }\end{array}$ & 0.99 & 0.99 & 0.99 & 0.93 & 1.00 & 0.95 & 0.62 \\
\hline Flexibility & 0.98 & 0.94 & 0.92 & 0.95 & 0.99 & 0.89 & 0.66 \\
\hline Responsiveness & 0.97 & 0.94 & 0.97 & 0.93 & 0.99 & 0.88 & $0.75 \& 0.71$ \\
\hline Automotive quality & 0.96 & 0.94 & 0.91 & 0.93 & 0.91 & 0.80 & 0.60 \\
\hline $\begin{array}{l}\text { Sustainable } \\
\text { knowledge } \\
\text { management }\end{array}$ & 0.96 & 0.92 & 0.94 & 0.92 & 0.94 & 0.83 & 0.62 \\
\hline
\end{tabular}


Customer recall concerns

$$
0.96 \quad 0.92
$$

1.00

0.98

0.99

0.89

0.85

${ }^{*}$ Cronbach's alpha values exceed 0.70 exhibit reliability. The critical ratio (CR) and associated p-value for a one-tailed test of significance are as follows: CR 1/41.28, p-value o0.10; CR1/41.64, p-value o0.05; CR1/42.33, p-valueo0.01; CR1/43.10, p-valueo0. 001.

Table 4 provides the goodness of fit results. The results indicate that all models exhibit fit indices with a score of 0.90 or greater, implying that all models have a satisfactory fit and that all of the items are valid in reflecting their corresponding constructs.

Table 4. Goodness of fit of the model

\begin{tabular}{lcccccc}
\hline Fitting Index & CMIN/DF & NFI & IFI & CFI & RMR & RMSEA \\
\hline Evaluation criterion & $<3$ & $>0.9$ & $>0.9$ & $>0.9$ & $>0.9$ & $<0.05$ \\
Test value & 2.784 & 0.912 & 0.921 & 0.920 & 0.016 & 0.081 \\
\hline
\end{tabular}

Table 5 presents the results of the convergent validity assessment that shows whether items underlying a specific construct are convergent or share a high proportion of variance in common (Hair et al., 2009). To establish convergent validity, the significance of item factor loading, average variance extracted (AVE), and construct reliability (CR) are assessed (Hair et al., 2009). Firstly, the study assesses examined multi-collinearity for prediction by using SPSS software. Then, the study examines the relevance of the CBSEM model relationships using an SPSS AMOS module.

As seen from Table 5 and Figure 4, the coefficient of the relationship between automotive recall concerns and the social sustainability performance of SCs has the highest coefficient value, 0.62 . The relationship of buyer-supplier relationship with automotive recalls and social sustainability performance achieves coefficient values of 0.48 and 0.53 , respectively. The buyer-supplier relationship dimension implies that automotive buyers should employ a social responsibility feedback system for monitoring and managing customer concerns associated with automotive recalls. According to the results, $\mathrm{p}$-values are smaller than 0.05 , meaning that the results are statistically significant. Therefore, we do not reject H1, H2, and H3. 
Table 5. Results for structural model evaluation

\begin{tabular}{lllll}
\hline Hypotheses & Path Direction & $\begin{array}{l}\text { Path } \\
\text { coefficient }\end{array}$ & $\begin{array}{l}\text { P- } \\
\text { Value }\end{array}$ & $\begin{array}{l}\text { Acceptance } \\
\text { Result }\end{array}$ \\
\hline $\mathrm{H} 1$ & $\begin{array}{l}\text { Buyer-supplier relationship } \rightarrow \\
\rightarrow \text { Social sustainability performance }\end{array}$ & 0.53 & $* * *$ & Accepted \\
$\mathrm{H} 2$ & $\begin{array}{l}\text { Buyer-supplier relationship } \rightarrow \\
\rightarrow \text { Automotive recall concerns }\end{array}$ & 0.48 & 0.0002 & Accepted \\
$\mathrm{H} 3$ & $\begin{array}{l}\text { Automotive recall concerns } \rightarrow \\
\rightarrow \text { Social sustainability performance }\end{array}$ & 0.62 & $* * * *$ & Accepted \\
\hline
\end{tabular}

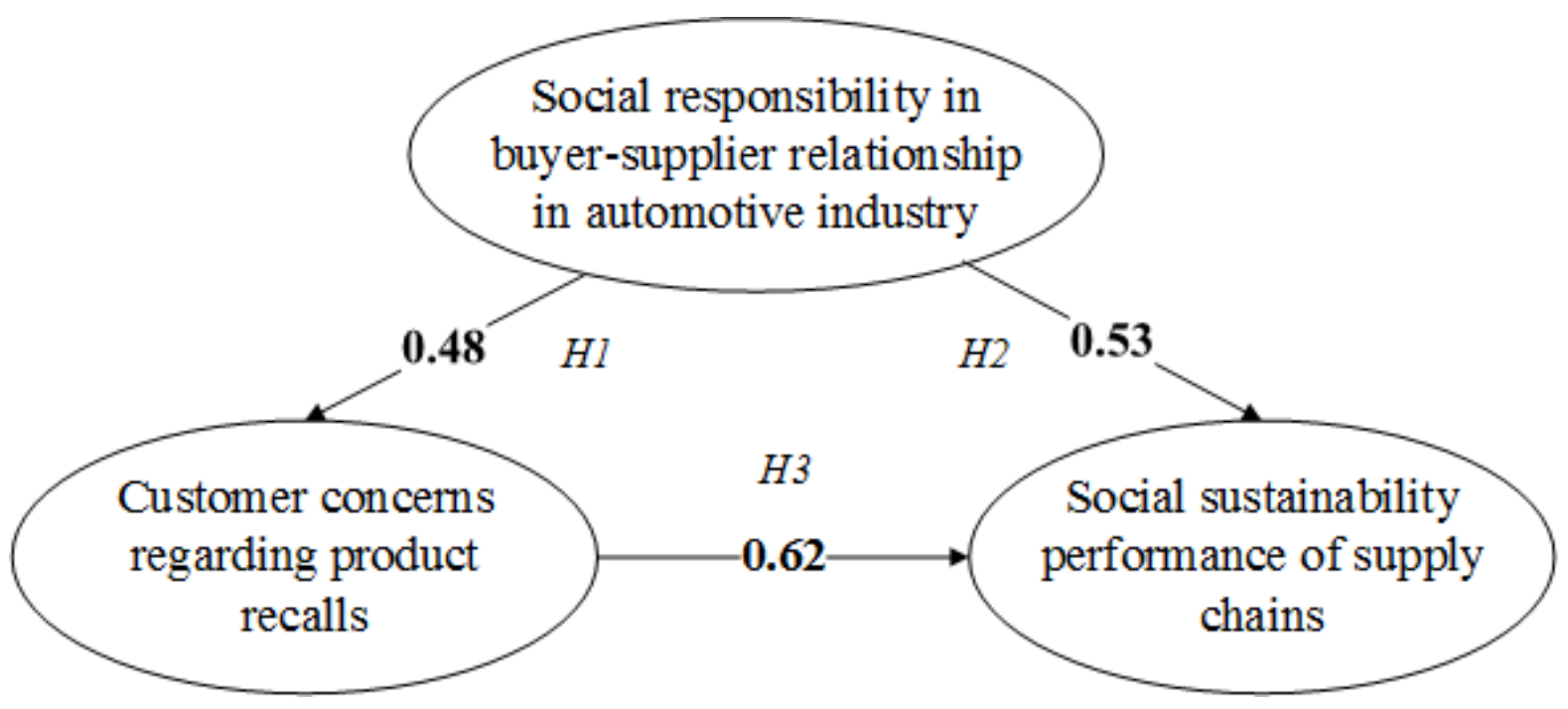

Figure 4. Structural equation model of the study

Table 6 provides the means, standard deviations, correlations, and chi-square differences of the five pre-identified categories of the social sustainability performance. The results in Table 6 reveal that the automotive buyer companies always have to be ready to update their responsible relationships and share knowledge with their top-tier suppliers. This can help automotive buyer companies to be involved in the ethics-related problem-solving efforts of their suppliers, especially during manufacturing recalls (Zhu, 2004; Miemczyk and Luzzini, 2016; Wilhelm et al., 2016a-b). Automotive companies need such an interrelationship to be dynamic for problem-solving once the automotive recall comes into play (Amann et al., 2014; Kumar and Rahman, 2016). 
Table 6. Mean, standard deviations, correlations, and chi-square differences

\begin{tabular}{|c|c|c|c|c|c|c|c|c|c|c|}
\hline $\begin{array}{r}\text { Social } \\
\text { sustainability } \\
\text { performance and } \\
\text { scale items }\end{array}$ & Mean & SD & 1 & 2 & 3 & 4 & 5 & 6 & 7 & 8 \\
\hline $\begin{array}{r}\text { Social and } \\
\text { environmental } \\
\text { responsibility }\end{array}$ & 2.45 & 0.69 & $\begin{array}{l}55 \\
* *\end{array}$ & & & & & & & \\
\hline Flexibility & 2.66 & 0.74 & $\begin{array}{l}38.5 \\
* * *\end{array}$ & $\begin{array}{l}0.39 \\
* *\end{array}$ & & & & & & \\
\hline Responsiveness & 2.67 & 0.84 & $\begin{array}{c}0.49 \\
* *\end{array}$ & $\begin{array}{l}34.1 \\
* * *\end{array}$ & $\begin{array}{l}73.7 \\
* * *\end{array}$ & & & & & \\
\hline Automotive quality & 1.96 & 0.80 & $\begin{array}{l}77.6 \\
* * *\end{array}$ & $\begin{array}{l}0.60 \\
* *\end{array}$ & $\begin{array}{c}0.25 \\
* *\end{array}$ & $\begin{array}{c}11.28 \\
* *\end{array}$ & & & & \\
\hline $\begin{array}{r}\text { Sustainable } \\
\text { knowledge } \\
\text { management }\end{array}$ & 2.96 & 0.76 & $\begin{array}{c}0.20 \\
* *\end{array}$ & $\begin{array}{l}0.40 \\
* *\end{array}$ & $\begin{array}{c}0.46 \\
* *\end{array}$ & $\begin{array}{l}34.5 \\
* * *\end{array}$ & $\begin{array}{c}0.53 \\
*\end{array}$ & & & \\
\hline $\begin{array}{r}\text { Customer recall } \\
\text { concerns }\end{array}$ & 1.96 & 0.62 & $\begin{array}{c}114.5 \\
*\end{array}$ & $\begin{array}{l}0.68 \\
* *\end{array}$ & $\begin{array}{c}0.54 \\
* *\end{array}$ & $\begin{array}{l}31.7 \\
* * *\end{array}$ & $\begin{array}{c}0.45 \\
* *\end{array}$ & $\begin{array}{c}0.53 \\
*\end{array}$ & $\begin{array}{c}0.54 \\
* *\end{array}$ & $\begin{array}{c}0.46 \\
* *\end{array}$ \\
\hline
\end{tabular}

\subsection{Discussion}

The findings of the study provide evidence of the relationship between responsible buyersupplier relational ties and customer recall concerns in the UK automotive industry. It also confirms the associated impact on the social sustainability performance of supply chains. These findings support extant literature through demonstrating how social sustainability practices in the upstream SC chain can help to improve social sustainability performance in the downstream SC (Leppelt et al., 2013). Five key indicators of social sustainability performance were identified for the automotive sector, and three research hypotheses were developed and accepted. Social responsibility in buyer-supplier relationships in the automotive industry was proved to reduce customer concerns regarding product recalls. This suggests that automotive manufacturers should develop better backward information sharing mechanisms with their suppliers regarding customer automotive recall concerns. As a result, improved collaborative managerial actions should be implemented not only to monitor and manage these concerns but also to mitigate the risks of product recalls. This study confirms that responsible buyer-supplier relationships can be considered as enablers to minimise customer concerns related to automotive recalls and, in turn, improve social sustainability performance. It is contended that identifying the enablers of reducing customer concerns in the automotive industry has been 
under-researched in the extant literature (Bruccoleri et al., 2018). The findings of this study provide new insights to better manage the vehicle recall risk, diminish customer recall concerns and enhance social sustainability performance.

\section{Conclusion}

Product recall is one of the most disruptive risks for social sustainability, especially in the automotive industry. This risk may cause many long-term disruptions and losses including financial losses, damage to brand image and trust, deterioration of market share, and even health and safety problems. This study has addressed product recalls as a growing sustainability concern that needs further academic investigation. The literature on socially sustainable SCs and buyer-supplier relationships has been integrated to generate a general framework for managing customer recall concerns through developing ethical and responsible ties among SC partners. The role and importance of responsible buyer-supplier relationships concerning recovery from a product recall crisis and improvement of social sustainability are emphasised based on the empirical results. First, five main categories have been identified and defined as social sustainability performance indicators through literature review: i) social and environmental responsibility, ii) flexibility, iii) responsiveness, iv) automotive quality, and v) sustainable knowledge management. The study combines a triangulation method for data collection (ISM) and a linear structural relationship of SEM to build the models, along with the help of experts in the automotive industry. The ISM method has been used to analyse social sustainability performance indicators and their interrelationship. Discussions and interviews conducted with experts, used to construct a structural self-interaction matrix, have then been used in structuring the ISM-based model. ISM has been embedded to provide qualitative factors to measure the impact of the responsible buyer-supplier relationship on customer concerns related to automotive recalls. Later, the relationship between the latent variables including social sustainability performance of supply chains, buyer-supplier responsible relationship and automotive recall concerns were examined by employing the CBSEM approach to a number of manifest variables. The proposed methodology examined the interrelationships between three main research variables considering the magnitude of the individual as well as the total impact. The buyer-supplier relationship dimension implies that automotive buyers should employ a social responsibility feedback system for monitoring and 
managing customer concerns associated with automotive recalls.

\subsection{Contribution to theory}

There are a limited number of research studies on social sustainability in SCs and the strategies to cope with associated challenges. The study offers better understanding of how supply chain management decisions affect society and the environment in the automotive industry which is an overlooked area in SC sustainability research (Wilhelm et al., 2016, Seuring and Müller, 2008). This study also contributes to the SSCM literature by proposing a structural model for the relationship between social sustainability, the buyer-supplier relationship, and product recall concerns in the automotive industry. The analysis supports this model by empirically exploring the proactive role of the buyer-supplier relationship during vehicle recalls through implementing CSR. Such a relationship is able to improve the social sustainability performance of both suppliers and buyers.

Furthermore, this study contributes to the theory by filling a gap on knowledge on the factors that may be used to minimise product recall risk and mitigate the negative effects of this disruptive risk on the social sustainability of SCs (Bruccoleri et al., 2018). In addition, this study provides a new theoretical insight in managing customer recall concerns through addressing the significance of buyer-supplier governance mechanisms for building socially responsible SCs in the market. The proposed mixed methodology that employs ISM and structural equation modelling provides empirical evidence for the findings.

\subsection{Contribution to practice}

The end customer's growing pressure on companies for sustainability and spread of this pressure to the supplier and sub-supplier level increases the importance of upstream SCs to improve ethical and responsibility performance. Ethical and socially responsible upstream SCs provide a competitive advantage through improved stakeholder management and visibility (Berns et al., 2009; Li et al., 2006). Both upstream and downstream relationships are very important, especially during product recall risk; nevertheless, this is generally overlooked by companies. This study empirically shows the importance of responsible buyer-supplier relationships for recovery from product recall crises and, in general, improvement of the social sustainability performance of SCs. The proposed structural framework and empirical results provide critical insights for SC practitioners to develop proactive strategies for product recall and enhance the robustness of their SCs. 
The study informs automotive manufacturers about the significance of developing strong, responsible, relational ties with their suppliers for eliminating customer recall concerns through better managing these concerns. The findings of the integrated ISM and CBSEM methodology reveal that, if automotive buyers do not build a strong, responsible relationship at the strategic level with their suppliers, the policies of CSR and performance will be unsustainable, especially during the recall crisis. Secondly, the findings also show that if companies do not enhance their responsible buyer-supplier relationships, the effect of customer recalls will be devastating, and it will be harder to manage existing recall concerns. Socially responsible feedback systems should be integrated by automotive buyer companies to monitor and manage customer concerns associated with automotive recalls effectively. Thirdly, the most important factors for the development of these relational ties are also addressed and explained in detail for the automotive industry. The rapid development of quality, information technology, communication and collaboration, and knowledge-sharing bring new opportunities for developing strategies to successfully manage the growing product recall risk. This requires developing a socially responsible feedback system that should be integrated by automotive buyer companies to monitor and manage customer concerns associated with automotive recalls. As a result, improved social sustainability performance can be achieved by applying the proposed strategies and approaches in the automotive sector.

\subsection{Limitations and future research dimensions}

This study has several limitations which provide scope for future research opportunities and a possible extension of the present work. The data set gathered from the automotive industry is limited and, hence, difficult to generalise, globally. Although the automotive industry has the greatest share of lost costs related to product recall, recent statistics show an increasing global trend in this risk in many different sectors such as food, pharmaceuticals, etc. Therefore, future research can include data from other industries and different regions for the validation of the findings (which will also result in a more accurate confirmatory factor analysis). Finally, although the 15 pairs of responsible buyer-supplier relationships in the data-set of this study can be deemed acceptable when compared with similar, prior studies (e.g., Luo, 2006; Krause et al., 2007), examination of the impact of other relationships within SC networks is another future research direction for the investigation of product recall risk and its mitigation. 


\section{REFERENCES}

ADSV (2014). Manufacturers' Guide to Recalls in the UK Automotive Sector. Driver \& Vehicle Standards Agency, 2 (04/14), https://assets.publishing.service.gov.uk/government/uploads/system/uploads/attachment d ata/file/302389/manufacturers-guide-to-recalls-in-the-uk-automotive-sector.pdf (22 June 2019).

Agustin, T.L.D., Schröder, M. (2015). The Indian Automotive Industry and the ASEAN Supply Chain Relations. ERIA Discussion Paper Series, http:/www.eria.org/ERIA-DP-201524.pdf (19 June 2018).

Ahi, P., Searcy, C. (2013). A comparative literature analysis of definitions for green and sustainable supply chain management. Journal of Cleaner Production, 52, 329-341.

Akdeniz, M.B., Calantone, R.J., Voorhees, C.M. (2014). Signalling Quality: An Examination of the Effects of Marketing- and Nonmarketing-Controlled Signals on Perceptions of Automotive Brand Quality. Journal of Product Innovation Management, 31(4), 728-743.

Allianz (2017). Product recall - Managing the impact of the new risk landscape. https://www.agcs.allianz.com/news-and-insights/reports/product-recall.html $\quad(18$ June 2019).

Amann, M., Roehrich, J.K., Eßig, M., Harland, C. (2014). Driving sustainable supply chain management in the public sector: The importance of public procurement in the European Union. Supply Chain Management: An International Journal, 19(3), 351-366.

Aragon, A., Huber, U., Möller, T., Nick, H. (2019). Return to sender: Resolving the automotive-recall resurgence. https://www.mckinsey.com/industries/automotive-andassembly/our-insights/return-to-sender-resolving-the-automotive-recall-resurgence June 2019).

Attri, R. Dev, N., Sharma, V. (2013). Interpretive Structural Modelling (ISM) approach: An Overview. Research Journal of Management Sciences, 2(2), 3-8.

Azevedo, S., Barros, M. (2017). The application of the triple bottom line approach to sustainability assessment: The case study of the UK automotive supply chain. Journal of Industrial Engineering and Management, 10(2), 286-322.

Bates, H., Holweg, M., Lewis, M., Oliver, N. (2007). Motor vehicle recalls: Trends, patterns and emerging issues. Omega, 35(2), 202-210.

Benoît, C., Norris, G.A., Valdivia, S., Ciroth, A., Moberg, A., Bos, U., Prakash, S., Ugaya, C., Beck, T. (2010). The guidelines for social life cycle assessment of products: just in time! The International Journal of Life Cycle Assessment, 15(2), 156-163.

Berns, M., Townend, A., Khayat, Z., Balagopal, B., Reeves, M., Hopkins, M.S., Kruschwitz, N. (2009). Sustainability and Competitive Advantage. MIT Sloan Management Review, 51(1), 18-27.

Beske, P., Seuring, S. (2014). Putting sustainability into supply chain management. Supply Chain Management: An International Journal, 19(3), 322-331.

Boyko, C.T., Gaterell, M.R., Barber, A.R.G, Brown, J., Bryson, J.R. et al. (2012). Benchmarking sustainability in cities: The role of indicators and future scenarios. Global Environmental Change, 22(1), 245-254.

Caniëls, M.C.J., Gehrsitz, M.H., Semeijn, J. (2013). Participation of suppliers in greening supply chains: An empirical analysis of German automotive suppliers. Journal of Purchasing \& Supply Management, 19(3), 134-143. 
Carter, C.R., Jennings, M.M. (2002). Social responsibility and supply chain relationships. Transportation Research Part E: Logistics and Transportation Review, 38(1), 37-52.

Chen, X. (2015). A Sustainability Analysis on the Wuhan-Guangzhou High-Speed Railway in China. International Journal of Sustainable Transportation, 9(5), 348-363.

Chen, Y., Ganesan, S., Liu, Y. (2009). Does a firm's product-recall strategy affect its financial value? An examination of strategic alternatives during product-harm crises. Journal of Marketing, 73(6), 214-226.

Choi, Y. and Y.-H. P. R. R. Lin, 35 (1), 18-22. (2009). Consumer response to crisis: Exploring the concept of involvement in Mattel product recalls. Public Relation Review, 35(1), 18-22.

Churchill, G.A. (1979). A Paradigm for Developing Better Measures of Marketing Constructs. Journal of Marketing Research, 16(1), 64-73.

Ciravegna, L., Romano, P., Pilkington, A. (2013). Outsourcing practices in automotive supply networks: an exploratory study of full-service vehicle suppliers. International Journal of Production Research, 51(8), 2478-2490.

Consumers Union (2004). Consumer Reports investigates the trouble with recalls. Consumer Reports. https://consumersunion.org/news/consumer-reports-investigates-the-trouble-withrecalls/ (22 June 2019)

Corsten, D., Gruen, T., Peyinghaus, M. (2011). The effects of supplier-to-buyer identification on operational performance - An empirical investigation of inter-organisational identification in automotive relationships. Journal of Operations Management, 29(6), 549560 .

Danese, P., Bortolotti, T. (2014). Supply chain integration patterns and operational performance: a plant-level survey-based analysis. International Journal of Production Research, 52(23), 7062-7083.

Dos Santos, S.F., Brandi, H.S. (2015). Model framework to construct a single aggregate sustainability indicator: an application to the biodiesel supply chain. Clean Technologies and Environmental Policy, 17(7), 1963-1973.

Dyer, J., H., and W. Chu (2003). The role of trustworthiness in reducing transaction costs and improving performance: Empirical evidence from the United States, Japan and Korea. Organization Science 14(I January-February), 57-68.

Dyer, J.H., Singh, H. (1998). The Relational View: Cooperative Strategy and Sources of Interorganizational Competitive Advantage. Academy of Management Review, 23(4), 660679.

Fernández, P., Del Rio, M.L., Varela, J., Bande, B. (2010). Relationships among functional units and new product performance: The moderating effect of technological turbulence. Technovation, 30(5-6), 310-321.

Flynn, B., Huang, X., Zhao, X. (2015). Supply chain management in emerging markets: critical research issues. Journal of Supply Chain Management, 51(1), 3-4.

Flynn, B.B., Huo, B., Zhao, X. (2010). The impact of supply chain integration on performance: A contingency and configuration approach. Journal of Operations Management, 28(1): 5871.

Fritz, V. (2018). BMW recall: What owners need to do. https://www.bbc.co.uk/news/business44068042 (Accessed on 25 June 2019).

Garbie, I.H. (2014). An analytical technique to model and assess sustainable development 
index in manufacturing enterprises. International Journal of Production Research, 52(16), 4876-4915.

Glavas, A., Mish, J. (2015). Resources and Capabilities of Triple Bottom Line Firms: Going Over Old or Breaking New Ground? Journal of Business Ethics, 127(3), 623-642.

Gopal, P.R.C., Thakkar, J. (2016). Analysing critical success factors to implement sustainable supply chain practices in Indian automobile industry: a case study. Production Planning \& Control, 27(12), 1005-1018.

Griffith, D.A., Zhao, Y. (2015). Contract Specificity, Contract Violation, and Relationship Performance in International Buyer-Supplier Relationships. Journal of International Marketing, 23(3), 22-40.

Grimm, J. H., Hofstetter, J.S., Sarkis, J. (2014). Critical factors for sub-supplier management: A sustainable food supply chains perspective. International Journal of Production Economics, 152, 159-173.

Gualandris, J., Kalchschmidt, M. (2016). Developing environmental and social performance: the role of suppliers' sustainability and buyer-supplier trust. International Journal of Production Research, 54(8), 2470-2486.

Gupta, K., Laubscher, R.F., Davim, J.P., Jain, N.K. (2016). Recent developments in sustainable manufacturing of gears: a review. Journal of Cleaner Production, 112(4), 3320-3330.

Hair, J.F., Black, W. C., Babin, B. J., Anderson, R. E. (2009). Multivariate data analysis. 7th ed., Pearson.

River, New Jersey: Pearson Education International.

Harms, D. (2011). Sustainability and internal supply chain management - A conceptual approach to intra-organisational knowledge transfer. The Corporate Responsibility Research

Conference, http://www.crrconference.org/Previous_conferences/downloads/crrc2011harms.pdf June 2018).

Ho, W., Zheng, T., Yildiz, H., Talluri, S. (2015). Supply chain risk management: a literature review. International Journal of Production Research, 53(16), 5031-5069.

Hong, J., Zhang, Y., Ding, M. (2018). Sustainable supply chain management practices, supply chain dynamic capabilities, and enterprise performance. Journal of Cleaner Production, $172,3508-3519$.

Hull, R. (2019). DVSA wants the MOT test to include checks for outstanding safety recalls that could see 1 in 13 UK cars FAIL. https://www.thisismoney.co.uk/money/cars/article6557589/DVSA-wants-MOT-test-include-checks-outstanding-safety-recalls.html (18 June 2019).

Hult, G.T.M. (2011). Market-focused sustainability: market orientation plus!. Journal of the Academy of Marketing Science, 39(1).

Hutchins, M. J., Sutherland, J.W. (2008). An exploration of measures of social sustainability and their application to supply chain decisions. Journal of Cleaner Production, 16(15), 1688-1698.

Kannan, G., Pokharel, S., Kumar, P.S. (2009). A Hybrid Approach Using ISM and Fuzzy TOPSIS for the Selection of Reverse Logistics Provider. Resources, Conservation and Recycling, 54(1), 28-36.

Kordestani, A., Amini, M., Salehi-Sangari, E. (2014). Environmentally and Socially 
Responsible Buyer-Supplier Relationship Management. In: Kubacki K. (eds) Ideas in Marketing: Finding the New and Polishing the Old. Developments in Marketing Science: Proceedings of the Academy of Marketing Science, Springer, 445-446.

Kumar, D., Rahman, Z. (2016). Buyer-supplier relationship and supply chain sustainability: empirical study of Indian automobile industry. Journal of Cleaner Production, 131, 836848.

Kumar, S., Schmitz, S. (2011). Managing recalls in a consumer product supply chain - root cause analysis and measures to mitigate risks. International Journal of Production Research, 49(1), 235-253.

Spence, L., Bourlakis, M. (2009). The evolution from corporate social responsibility to supply chain responsibility: the case of Waitrose. Supply Chain Management: An International Journal, 14(4), 291-302.

Lee, C.K.M., Lam, J.S.L. (2012). Managing reverse logistics to enhance sustainability of industrial marketing. Industrial Marketing Management, 41(4), 589-598.

Leppelt, T., Foerstl, K., Hartmann, E. (2013). Corporate Social Responsibility in BuyerSupplier Relationships: Is it Beneficial for Top-Tier Suppliers to Market their Capability to Ensure a Responsible Supply Chain? Business Research, 6(2), 126-152.

Lewis, M., Brandon-Jones, A., Slack, N., Howard, M. (2010). Competing through operations and supply: The role of classic and extended resource-based advantage. International Journal of Operations \& Production Management, 30(10), 1032-1058.

Li, S., Ragu-Nathan, B., Ragu-Nathan, T.S., Rao, S.S. (2006). The impact of supply chain management practices on competitive advantage and organisational performance. Omega, 34(2), 107-124.

Lim, M. K., Tseng, M.L., Tan, K.H., Bui, T.D. (2017). Knowledge management in sustainable supply chain management: Improving performance through an interpretive structural modelling approach. Journal of Cleaner Production, 162, 806-816.

Linderbaum, B.A., Levy, P.E. (2010). The development and validation of the Feedback Orientation Scale (FOS). Journal of Management, 36(6), 1372-1405.

Liu, Y., Huang, Y., Luo, Y., Zhao, Y. (2012). How does justice matter in achieving buyersupplier relationship performance?. Journal of Operations Management, 30(5), 355-367.

Ma, Z.X., Li, P.P., Yi, R. (2013). The Efficiency Analysis of R\&D Activities for Listed High Technology Enterprises in Western China. Applied Mechanics and Materials, Vols. 380384, 4516-4520.

Mansouri, N. (2016). A Case Study of Volkswagen Unethical Practice in Diesel Emission Test. International Journal of Science and Engineering Applications, 5(4), 211-216.

Mao, Z., Jin, Y. (2014). Reverse Logistics in Automotive Industry: A multiple case study in automotive industry. Master thesis, University of Gävle, Faculty of Engineering and Sustainable Development.

Marucheck, A., Greis, N., Mena, C., Cai, L. (2011). Product safety and security in the global supply chain: Issues, challenges and research opportunities. Journal of Operations Management, 29(7-8), 707-720.

Matten, D. and J. Moon (2008). Implicit' and 'explicit' CSR: A conceptual framework for a comparative understanding of corporate social responsibility." Academy of Management Review, 33(2), 404-424. 
Meckenstock, J., Barbosa-Póvoa, A.P., Carvalho, A. (2016). The Wicked Character of Sustainable Supply Chain Management: Evidence from Sustainability Reports. Business Strategy and the Environment, 25, 449-477.

Meixell, M.J., Luoma, P. (2015). Stakeholder pressure in sustainable supply chain management: a systematic review. International Journal of Physical Distribution \& Logistics Management, 45(1/2), 69-89.

Miemczyk, J., Luzzini, D. (2016). Sustainable Purchasing: The Influence on Risk Practices on the Triple Bottom Line. 7th EDSI Conference, Finland, https://vtk.uninke.hu/document/vtk-uni-nke-hu/edsi2016proceedingsfinal.original.pdf (19 June 2018).

Mori, K., Christodoulou, A. (2012). Review of sustainability indices and indicators: Towards a new City Sustainability Index (CSI). Environmental Impact Assessment Review, 32(1), 94-106.

Narayanan, S., Narasimhan, R. (2014). Governance Choice, Sourcing Relationship Characteristics, and Relationship Performance. Decision Sciences, 45(4), 717-751.

Ni, J.Z., Flynn, B.B., Jacobs, F.R. (2014). Impact of product recall announcements on retailers' financial value. International Journal of Production Economics, 153, 309-322.

Noack, D., Miller, D.R., Smith, D. (2017). Let Me Make It Up to You: Understanding the Mitigative Ability of Corporate Social Responsibility Following Product Recalls. Journal of Business Ethics.

Panackal, N., Singh, A. (2015).Using Interpretive Structural Modeling to Determine the Relation between Youth and Sustainable Rural Development. IBMRD's Journal of Management and Research, 4(1), 58-74.

Pathak, A., et al. (2010). Nasal carriage and antimicrobial susceptibility of Staphylococcus aureus in healthy preschool children in Ujjain, India. BMC pediatrics 10(1), 100.

Pava, M.L. (2008). Why Corporations Should Not Abandon Social Responsibility. Journal of Business Ethics, 83(4), 805-812.

Ravi, V., Shankar, R. (2005). Analysis of interactions among the barriers of reverse logistics. International Journal of Technological Forecasting \& Social change, 72(8), 1011-1029.

Quesada, G., Syamil, A., Doll, W.J. (2006). OEM New Product Development Practices: The Case of the Automotive Industry. Journal of Supply Chain Management, 42(3), 30-40.

Rupp, N.G. (2004). The attributes of a costly recall: Evidence from the automotive industry. Review of Industrial Organization, 25(1), 21-44.

Sancha, C., Wong, C.W.Y., Thomsen, C.G. (2016). Buyer-supplier relationships on environmental issues: a contingency perspective. Journal of Cleaner Production, 112(3), 1849-1860.

Schaltegger, S., Burritt, R. (2014). Measuring and managing sustainability performance of supply chains: Review and sustainability supply chain management framework. Supply Chain Management: An International Journal, 19(3), 232-241.

Seuring, S., Müller, M. (2008). Core issues in sustainable supply chain management-a Delphi study. Business Strategy and the Environment, 17(8), 455-466.

Seuring, S., Müller, M. (2008b). From a literature review to a conceptual framework for sustainable supply chain management. Journal of Cleaner Production, 16, 1699-1710.

Shah, R., Ball, G., Netessine, S. (2016). Plant operations and product recalls in the automotive industry: An empirical investigation. INSEAD Working Paper No. 2016/01/TOM. 
https://papers.ssrn.com/sol3/papers.cfm?abstract_id=2356315 (accessed 15 June 2018).

Shahabadkar, P., Hebbal, S.S., Prashant, S. (2012). Deployment of Interpretive Structural Modeling Methodology in Supply Chain Management -An Overview. International Journal of Industrial Engineering \& Production Research, 23(3), 195-205.

Shibin, K. T., Gunasekaran, A., Dubey, R. (2017). Explaining sustainable supply chain performance using a total interpretive structural modeling approach. Sustainable Production and Consumption, 12, 104-118.

Stadtler, H. (2015). Supply Chain Management: An Overview. In: Stadtler H., Kilger C., Meyr H. (eds) Supply Chain Management and Advanced Planning. Springer Texts in Business and Economics. Springer, Berlin, Heidelberg, 3-28.

Stericycle (2019). European Recall \& Notifications Index - Q1 2019. Stericycle Expert Solutions, https://www.stericycleexpertsolutions.co.uk/recall-index/ (18 June 2019).

Steven, A. B., Dong, Y., Corsi, T. (2014). Global sourcing and quality recalls: An empirical study of outsourcing-supplier concentration-product recalls linkages. Journal of Operations Management, 32(5), 241-253.

Tate, W.L., Bals, L. (2016). Achieving Shared Triple Bottom Line (TBL) Value Creation: Toward a Social Resource-Based View (SRBV) of the Firm. Journal of Business Ethics, 124.

Tate, W. L., et al. (2010). Corporate social responsibility reports: a thematic analysis related to supply chain management. Journal of Supply Chain Management 46(1): 19-44.

Thirupathi, R.M., Vinodh, S. (2016) Application of interpretive structural modelling and structural equation modelling for analysis of sustainable manufacturing factors in Indian automotive component sector. International Journal of Production Research, 54(22), 66616682.

Thomé, A.M.T., Scavarda, L.F., Pires, S.R.I., Ceryno, P. (2014). A multi-tier study on supply chain flexibility in the automotive industry. International Journal of Production Economics, 158, 91-105.

Touboulic, A., Chicksand, D., Walker, H. (2014). Managing Imbalanced Supply Chain Relationships for Sustainability: A Power Perspective. Decision Sciences, 45(4), 577-619.

Tsalis, T., Avramidou, A., Nikolaou, I.E. (2017). A social LCA framework to assess the corporate social profile of companies: Insights from a case study. Journal of Cleaner Production, 164, 1665-1676.

Turnbull, P., Oliver, N., Wilkinson, B. (1992). Buyer-supplier relations in the UK - automotive industry: Strategic implications of the Japanese manufacturing model. Strategic Management Journal, 13(2), 159-168.

Van Tulder, R., Van Wijk, J., Kolk, A. (2008). From Chain Liability to Chain Responsibility: MNE Approaches to Implement Safety and Health Codes in International Supply Chains . Journal of Business Ethics, 85(2), 399-412.

Wang, J., Li, J., Arinez, J., Biller, S. (2012). Indicators for quality improvability and bottleneck sequence in flexible manufacturing systems with batch production. International Journal of Production Research, 50(22), 6388-6402.

Wells, P. (2013). Sustainable business models and the automotive industry: A commentary. IIMB Management Review, 25(4), 228-239.

Wilhelm, M., Blome, C., Wieck, E., Xiao, C.Y. (2016a). Implementing sustainability in multi- 
tier supply chains: Strategies and contingencies in managing sub-suppliers. International Journal of Production Economics, 182, 196-212.

Wilhelm, M.M., Blome, C., Bhakoo, V., Paulraj, A. (2016b). Sustainability in multi-tier supply chains: Understanding the double agency role of the first-tier supplier. Journal of Operations Management, 41, 42-60.

Wu, F., Yeniyurt, S., Kim, D., Cavusgil, S.T. et al. (2006). The impact of information technology on supply chain capabilities and firm performance: A resource-based view. Industrial Marketing Management, 35(4), 493-504.

Yeung, H.W.C., Coe, N.M. (2015). Toward a Dynamic Theory of Global Production Networks. Economic Geography, 91(1), 29-58.

Yu, V.F., Tseng, L.C. (2014). Measuring social compliance performance in the global sustainable supply chain: an AHP approach. Journal of Information and Optimization Sciences, 35(1), 47-72.

Zhao, X., Li, Y., Flynn, B.B. (2013). The financial impact of product recall announcements in China. International Journal of Production Economics, 142(1), 115-123.

Zheng, J., Roehrich, J.K., Lewis, M.A. (2008). The dynamics of contractual and relational governance: Evidence from long-term public-private procurement arrangements. Journal of Purchasing and Supply Management, 14(1), 43-54.

Zhu, K. (2004). The Complementarity of Information Technology Infrastructure and ECommerce Capability: A Resource-Based Assessment of Their Business Value. Journal of Management Information Systems, 21(1), 167-202.

Zsidisin, G.A. (2003). A grounded definition of supply risk. Journal of Purchasing and Supply Management, 9(5-6), 217-224. 
Appendix 1. Digraph of the ISM hierarchical model

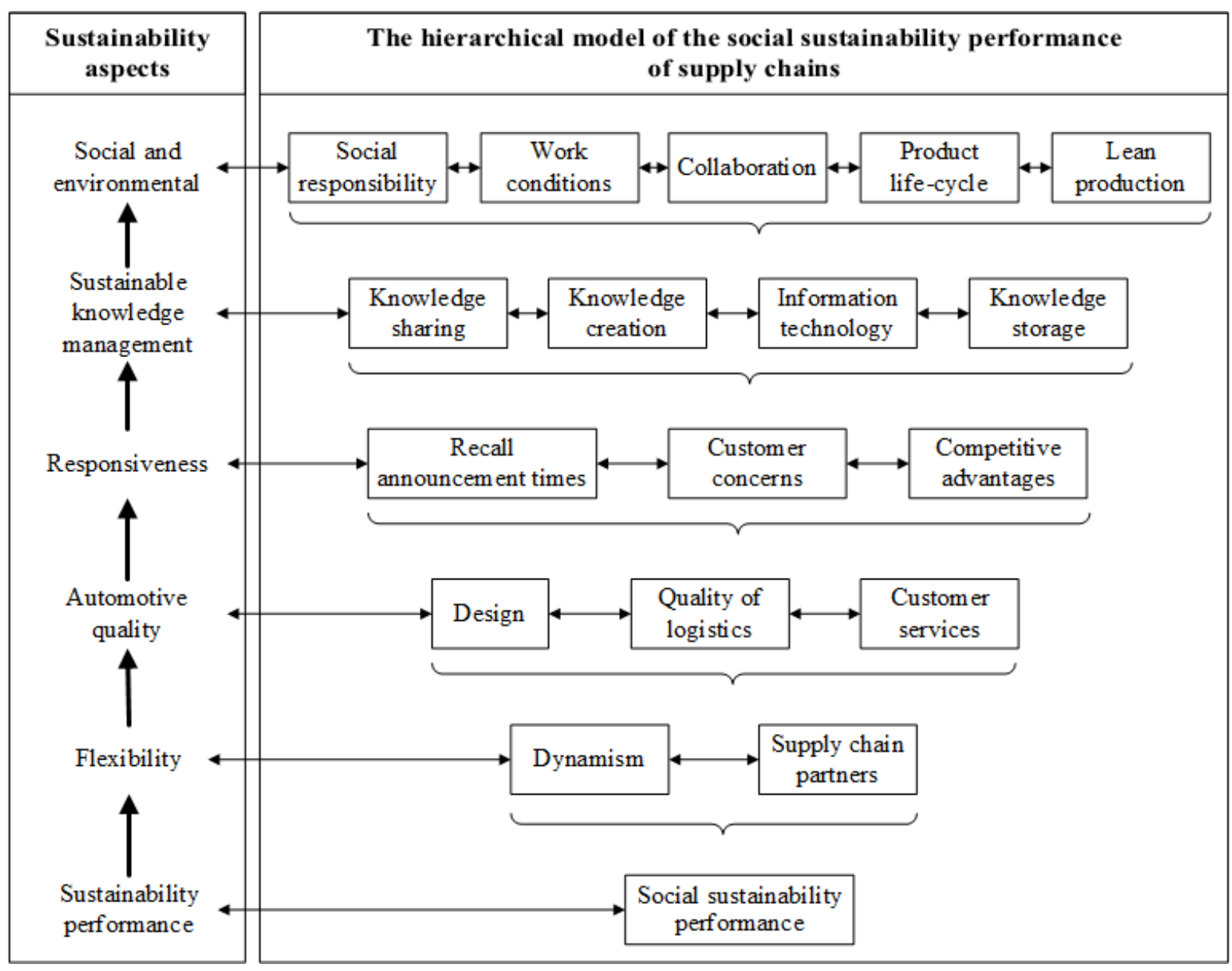


2019-10-04

\title{
Automotive recall risk: Impact of buyer-supplier relationship on supply chain social sustainability
}

\author{
Nassar, Shereen
}

Emerald

\author{
Nassar S, Kandil T, Er-Kara M, Ghadge A. (2019) Automotive recall risk: Impact of \\ buyer-supplier relationship on supply chain social sustainability. International Journal of \\ Productivity and Performance Management, Volume 69, Issue 3, 2019, pp. 467-487 \\ https://doi.org/10.1108/IJPPM-01-2019-0026 \\ Downloaded from Cranfield Library Services E-Repository
}

